\title{
Resenha
}

\section{DE MARCENEIRO A DOUTOR: JÚLIO ROMÃO DA SILVA, UM ARTESÃO DAS LETRAS}

\author{
Calila das Mercês ${ }^{1}$ \\ Raquel Galvão ${ }^{2}$
}

Referência da obra resenhada:

CAMPELO, Aci; FERREIRA, Élio. (Org.). Júlio Romão da Silva: entre o formão, a pena e a flecha: fortuna da obra de um escritor negro brasileiro. Teresina: EDUFPI, 2012.

\section{INTRODUÇÃO}

Uma edição urgente. Em um livro, registro e homenagem: Júlio Romão da Silva - Entre o formão, a pena e a flecha: fortuna da obra de um escritor negro brasileiro foi organizado e publicado em 2012 pelos professores Aci Campelo e Elio Ferreira, publicado pela Editora da Universidade Federal do Piauí (UFPI). Em tempo, a obra saiu um ano antes da morte do piauiense Júlio Romão da Silva (1917-2013), que ao longo dos seus 95 anos, deixou um importante legado no que tange à literatura negra brasileira — também nomeada ora de afrodescendente ora de afrobrasileira - e à etnolinguística indígena.

Ao certificar a atuação de Júlio Romão da Silva como jornalista, escritor, professor e agente literário brasileiro, os organizadores registraram a memória histórica de quase um século e reuniram uma fortuna crítica composta por 26 ensaios críticos e biográficos, entrevis-

1 Mestranda do Programa de Pós-Graduação em Estudos Literários da Universidade Estadual de Feira de Santana (PROGEL/UEFS). Endereço eletrônico: caliladasmerces@gmail.com. Orientador: Roberto H. Seidel.

2 Mestranda do Programa de Pós-Graduação em Estudos Literários da Universidade Estadual de Feira de Santana (PROGEL/UEFS). Endereço eletrônico: raquelgcultura@gmail.com. Orientadora: Állex Leilla. 
tas, obras e artigos protagonizados ou escritos por esse estudioso que durante a vida enfatizou a importância da valorização da identidade.

Autor de mais de 40 livros, obras de teatro, poesias e pesquisas etnolinguísticas, ocupou a cadeira 31 da Academia Piauiense de Letras em 1988 e recebeu o título de Dr. Honoris Causa da UFPI em 2010, Júlio Romão da Silva precisou resistir. Nos trilhos dessa resistência, o conjunto do livro percorre a emocionante trajetória profissional e acadêmica de um negro, que se alicerçou nas "letras" e com elas se sobressaiu.

\section{O FORMÃO}

Entre os doze ensaios críticos e entrevistas apresentados na coletânea, uma questão inicial se faz presente. De onde veio Júlio Romão da Silva? Nascido em Teresina, Júlio Romão se formou marceneiro aos 13 anos. Daí a metáfora do formão, importante ferramenta para entalhes em madeira. Contudo, o futuro escritor não se mostrava satisfeito com a profissão: queria estudar mais, como ratifica na entrevista Um aventureiro das Letras dada a Marcos Vilarinho ao Caderno Metrópole do Jornal O dia (2005):

\footnotetext{
Eu trabalhava muito bem; era muito exigente comigo mesmo. No entanto, apesar de ganhar um dinheirinho com essa profissão, eu queria mesmo era estudar, ser escritor, ser alguém que fosse motivo de orgulho para minha família porque, na época, os familiares se orgulhavam de ter um doutor, um homem de letras. Quando aparecia alguém formado, o povo corria para as portas, todo mundo admirava (CAMPELO; FERREIRA, 2012, p. 60).
}

Em busca do seu sonho, Júlio Romão da Silva partiu de Teresina para o Rio de Janeiro no porão de um navio cargueiro. Depois da viagem de oito dias, em 1936, chegou à então capital federal, tendo que dormir em um albergue para mendigos. Contudo, a partir dessa chegada ao Rio, fez o curso ginasial e formou-se pela Faculdade de Filosofia da Universidade do Brasil (denominação antiga da atual Universidade Federal do Rio de Janeiro). Foi nessa cidade que o ofício de escrita de Júlio Romão teve início.

\section{A PENA}

Em um só livro, informações divergem, principalmente, a respeito da atuação de comunicador do escritor piauiense. Alguns relatos sinalizam que, como jornalista, Júlio Romão atuou em vários veículos de comunicação do Rio de Janeiro. Entre eles, o Jornal do Comér- 
Pontos de Interrogação, v. 3, n. 1, jan./jul. 2013

Revista do Programa de Pós-Graduação em Crítica Cultural

Universidade do Estado da Bahia (UNEB), Campus II - Alagoinhas - BA

cio, Diário Carioca, O Malho, Vamos Ler, Revista da Semana, Dom Casmurro e no Correio da Manhã, tendo trabalhado como revisor, repórter e redator.

Depois dessa atividade da escrita jornalística, Júlio Romão da Silva exerceu o cargo de funcionário público do Instituto Brasileiro de Geografia e Estatística (IBGE), até se aposentar como técnico em comunicação social. Concomitantemente a essa atividade pública, o piauiense se dedicou a escrever livros e peças teatrais com enfoque na questão da negritude, assim como estudos de autores negros. Destacam-se na publicação, suas obras selecionadas: $A$ mensagem do Salmo (saga dramática do Cristianismo); José, o vidente (saga dramática de Israel); Luís Gama e suas poesias satíricas e Luís Gama: o mais consequente poeta satírico brasileiro: crítica à crítica. A respeito de estudos literários em Um legado de 90 anos de luta em forma de arte para a valorização de identidades para a Revista Sapiência, ele cita alguns negros ilustres da arte literária e o que eles fizeram de representativo:

\footnotetext{
Negros importantes estão marcados na história literária, como Luis Gama; Teodoro Sampaio, autor de "O Tupi" e mestre de Euclides da Cunha, com o qual eu me habilitei; Dom Silvério Pimenta, negro que chegou a bispo em Minas Gerais; André Rebouças; Solano Trindade, pernambucano, meu colega e um dos pioneiros do movimento negro no Brasil; Machado de Assis, um negro autodidata, nascido no morro, que chegou a fundar a ABL. Inclusive, negam que Machado teve influência na campanha abolicionista, mas eu estou escrevendo a biografia dele, na qual provo que ele teve influência, porém discreta (CAMPELO; FERREIRA, 2012, p. 87-88).
}

\section{A FLECHA}

Júlio Romão da Silva além de ter sido um importante ativista negro, sendo na década de 40 e 50 um agente de formação de organizações negras, uniu a sua flecha à dos índios na realização de pesquisas na área de etnolinguística indígena. Junto aos índios Bororós, realizou o estudo A família etnolinguística Bororó, apoiado, divulgado e difundido pelo IBGE. Sua curiosidade também o levou a realizar o estudo Tupi Língua Indígena Natural do Brasil, dedicado ao antropólogo brasileiro Darcy Ribeiro.

A flecha e também a pena de Julio Romão sempre estiveram apontadas para questões de memória e história do Brasil, incluindo a formação das suas cidades. O livro homenagem a Júlio Romão da Silva registra o ensaio Memória sobre a transferência da capital do Piauí. No que tange a uma abordagem sobre importantes personalidades brasileiras, aparecem textos sobre os também colaboradores do IBGE, Solano Trindade e Teodoro Sampaio. 
Um pronunciamento sobre o centenário de nascimento do poeta Castro Alves para à Rádio Globo é disponibilizado na íntegra no texto Louvado seja Castro Alves. Outro artista também homenageado em um artigo de Julio Romão da Silva é o escultor e entalhador mineiro Antônio Francisco Lisboa (Aleijadinho), em Aleijadinho, o leproso genial.

Sempre envolvido na dinâmica política do país, Júlio Romão da Silva aborda a histórica passagem de Getúlio Vargas em artigos que foram publicados no jornal O Dia de Teresina em 1997: Vargas: apogeu e um tiro no peito e Getúlio: carta e legado.

\section{IDENTIDADE, MINORIAS E REPRESENTAÇÃO}

Nota-se que Júlio Romão da Silva, conseguiu sem nomenclaturas pautar assuntos relevantes relacionados ao que hoje conhecemos como Estudos Culturais. A sua própria vida já descreve o caminho de um nordestino, negro, pobre que sai de casa em busca do saber e que, com todas as dificuldades, consegue "aparecer" e contribuir para os estudos literários brasileiros.

O pioneiro das lutas pela igualdade racial, nos anos 40, deixa, além de um legado importante para pesquisadores e artistas, o desejo de um país mais igualitário que realce a memória do seu povo e que saliente o hibridismo que sustenta a própria origem.

Recebido em: 17 de julho de 2013.

Aceito em: 30 de setembro de 2013. 